\title{
Fire-Resisting Composites Based on Polymer Matrix
}

\author{
V.A. Ushkov ${ }^{1}$, O.L. Figovsky ${ }^{2}$ \\ ${ }^{1}$ Moscow State University of Civil Engineering, Moscow, Russia \\ 2Polymate Ltd.-INRC, Migdal HaEmek, Israel \\ va.ushkov@yandex.ru; figovsky@gmail.com
}

Keywords: brominated fire retardants, flammability, combustibility, fume evolution index, epoxy matrix composites, fillers, plasticizers, ferrocene derivatives.

\begin{abstract}
In the present work we have studied the thermal stability, flammability, fume evolution of epoxy matrix composites with different types and amounts of hardeners, fillers, plasticizers and fire retardants. It is shown that chemical composition of fillers has little effect on the flammability of epoxy composites when the content of mineral fillers is less than $45 \%$ by mass. Smoke formation decreases linearly with increasing the degree of filling. It is shown that to obtain low-combustible materials the oxygen index should exceed $31 \%$. It was found that the optimal concentration of industrial brominated fire retardants is $8-10 \%$ by mass. To reduce the flammability of epoxy composites, additive brominated fire retardants in the form of a solution in N,N-dimethyl-2,4,6tribromoaniline have been proposed. The high efficiency of acetyl- and $\alpha$-hydroxyethyl ferrocene as a smoke suppressor of epoxy composites is shown.
\end{abstract}

\section{Introduction}

Nowadays, epoxy oligomers are widely used as binders in construction industry. Constructional composites with epoxy matrices - epoxy matrix composites (EMC) - are often characterized by unique combinations of operational properties. Broad range of available epoxy resins and hardeners allows precise control of elastic modulus (in case of continuous reinforcement fibers, the well known application is composite reinforcement), compressive and tensile strength, water, frost and chemical resistance of EMC [1-5]. Epoxy resins are used as binders for production of composite reinforcement (with carbon, basalt and glass fibers), chemically resistant paint coatings, polymer mortars and concretes, foams, adhesives and monolithic floor coverings [6-10]. EMC often outperform even advanced building materials with inorganic matrices [11], especially when the dispersed phases were subjects of special processing [12].

It is known that properties related to fire safety can be controlled by different means, including special mineral fillers and fire retardants [13-20,47]. The common approaches for improvement the performance of PMC against fire hazards involve usage of:

- flame retardants that reduce polymer combustibility, smoke and toxic fume production $[21,22]$;

- intumescent surface coatings [21,23].

At present, comprehensive nomenclature of flame retardants include halogen-based [24, 25] and phosphorus-based [26-30] substances. Recent achievements in flame retardant development are represented by organometallic [31], e.g. ferrocene [18, 32-34], and organosilicon (e.g. silsesquioxane) [1,35] compounds. In particular, addition of ferrocene leads to decrease of smoke density caused by sooting during combustion of both unsaturated [33] and saturated hydrocarbons. Ferrocene structures embedded in polymer chains lead to increase of thermal stability and/or fire resistance [32], though at least for several ferrocene derivatives there is a negative correlation between smoke suppression and flame retardancy [34].

Still, quantitative dependencies between amount, chemical type of admixtures and properties related to fire safety of EMC till now are not revealed in detail. The purpose of this work is to study the dependencies between flammability, combustibility, fume evolution of EMC and amount and chemical type of fillers and admixtures. 


\section{Materials and Methods}

Epoxy polymers were prepared on the base of ED-20 (RU GOST 10587-84) epoxy resin. Several types of hardeners are used: polyethylene polyamine (PEPA), diethylenetriamine, triethylenetetramine, imidazolines of "UP-0640", "UP-0641" and "UP-0642" and monoethanediethylethylene triamine "UP-0633M". The elastic characteristics of the composites were regulated by the use of low molecular mass butadiene-nitrile carboxylate rubbers "SKN-18-1A" and "SKN-26-1A", phosphate plasticizers (properties of these plasticizers are summarized in [35]), as well as "Parachlor-380" chlorpaffin with 54-57\% of chlorine. Oxides and hydroxides of various metals, goethite, marshalite, andesite, quartz sand and hydrate-containing minerals were used fine (325 microns) mineral fillers. The thermophysical properties of the metal oxides are summarized in [36]. Thermal properties of hydrate-containing minerals and decomposing mineral fillers are summarized in [37] and [38].

Industrial grades of brominated-oorganic fire retardants and synthesized "Redant" brominecontaining compounds were used to reduce the flammability of EMC. Physicochemical and thermal properties of "Redant" compounds are given in [39]. Ferrocene derivatives were used as smoke suppressors (properties of ferrocene derivatives are summarized in [40]). Depending on the degree of bromination of the initial chloroalkyl aromatic compound, the "Redant" fire retardants contain 15.5$26.5 \%$ chlorine and $44-46 \%$ bromine. For comparison, microencapsulated chladone "114B2", $\mathrm{CCl}_{4}$, ammonium polyphosphate and decabromodiphenyloxide (DBDFO), halogen-containing epoxy oligomers "Oksilin-6" and "UP-631", as well as bromination products of ED-22 epoxy oligomer and aniline-modified diglycidyl ether of tetrabromodian were used.

Thermal analysis of fillers, flame retardants, ferrocene derivatives and EMC in air and nitrogen flow was carried out using "DuPont-9900" automated modular thermoanalytical system (heating rate was $\left.10{ }^{\circ} \mathrm{C} / \mathrm{min}\right)$. Limiting oxygen index (LOI), ignition $\left(\mathrm{T}_{\mathrm{i}}\right)$ and autoignition $\left(\mathrm{T}_{\mathrm{si}}\right)$ temperature, fume evolution index $\left(\mathrm{D}_{\mathrm{m}}\right)$ in pyrolysis and flame combustion mode, heat of combustion, critical density of heat flux of ignition $\left(\mathrm{q}_{\mathrm{cr}}\right)$, limiting concentration of oxygen $\left(\mathrm{c}_{1}\right)$ and velocity of flame propagation $\left(\mathrm{V}_{\mathrm{pn}}\right)$ on the horizontal surface of epoxy polymers and EMC based on such polymers at different oxygen concentrations in the oxidizer stream were determined according to RU GOST 12.1.044 and methods given in [35-37].

\section{Results and Discussion}

The presence of epoxy (1-24\%) and hydroxyl (0,2-10\%) functional groups in diane epoxy resins allows them to be cured by various classes of organic, inorganic and organoelement compounds [35]. It has been established that the chemical structure of amine curing agents has little effect on the flammability and smoke-forming ability of epoxy composites [41]. Therefore, the choice of amine curing agents should be carried out only taking into account the required technological and operational parameters of epoxy composites.

An effective method of increasing the modulus and strength of EMC is the modification by various compounds [24]. Low-molecular organic compounds increase the combustibility and $\mathrm{D}_{\mathrm{m}}$ of EMC. Industrial grades of phosphate plasticizers increase the LOI and $\mathrm{T}_{\mathrm{si}}$ of epoxy binders from $22.1 \%$ and $470{ }^{\circ} \mathrm{C}$ up to $23.1-24.5 \%$ and $500-510^{\circ} \mathrm{C}$, respectively, reduce the q $\mathrm{q}_{\mathrm{cr}}$ value from 11.7 to 9.2-10.7 kW/m ${ }^{2}$ [20]. The low efficiency of phosphate plasticizers is due to their relatively high combustibility: LOI of plasticizers is $23.1-29.9 \%$, while LOI of ED-20 polymer is $21.6-22.3 \%$ [14]. At the same time, chemical type of plasticizers has a significant effect on the smoke-forming ability of EMC. For example, $\mathrm{D}_{\mathrm{m}}$ in pyrolysis and flame combustion mode of epoxy polymer plasticized by $8.3-15.4 \%$ by diphenyl(2-ethylhexyl)phosphate is reduced from 980 and $990 \mathrm{~m}^{2} / \mathrm{kg}$ down to to 910 $640 \mathrm{~m}^{2} / \mathrm{kg}$ and $840-970 \mathrm{~m}^{2} / \mathrm{kg}$, respectively. Trichloroethyl(propyl)phosphates increase $D_{m}$ in the pyrolysis mode.

If mass rate of mineral filler is less than $45 \%$, the chemical nature of filler has little effect on the fire hazard properies of epoxy composites: $\mathrm{LOI}$ is $19.8-22.3 \%, \mathrm{~T}_{\mathrm{i}}$ is $280-310{ }^{\circ} \mathrm{C}, \mathrm{T}_{\mathrm{si}}$ is $480-515{ }^{\circ} \mathrm{C}$, $\mathrm{q}_{\mathrm{cr}}$ is $10.6-16.2 \mathrm{~kW} / \mathrm{m}^{2}, \mathrm{D}_{\mathrm{m}}$ in the pyrolysis and combustion mode is $520-840$ and 350 - 
$540 \mathrm{~m}^{2} / \mathrm{kg}$, respectively (Table 1; amount of fillers is $43.5 \%$ by mass, amount of plasticizer is $8.7 \%$ by mass). Significant reduction of the fire hazard of EMC is observed when mass rate of mineral filler exceeds $50 \%$ : for $61 \%$ LOI grows up to $30.8 \%$, $\mathrm{T}_{\mathrm{i}}-$ up to $290-320{ }^{0} \mathrm{C}, \mathrm{T}_{\mathrm{si}}-$ up to $490-520{ }^{0} \mathrm{C}$, $\mathrm{q}_{\mathrm{cr}}$ is linearly increased from 10.3 to $12.2-18.5 \mathrm{~kW} / \mathrm{m}^{2}$. If mass rate of mineral filler is more than $20 \%$, than fume evolution index in the pyrolysis and flame combustion mode linearly decreases from 1470 and $800 \mathrm{~m}^{2} / \mathrm{kg}$ up to $460-550$ and $190-250 \mathrm{~m}^{2} / \mathrm{kg}$, respectively. This index only slightly depends on the chemical nature of the fillers [20].

Table 1. Properties related to fire safety of EMC.

\begin{tabular}{|c|c|c|c|c|c|c|}
\hline \multirow{3}{*}{ Fillers } & \multicolumn{6}{|c|}{ Properties } \\
\hline & \multirow{2}{*}{$\mathrm{T}_{\mathbf{s i}}$} & \multirow{2}{*}{$\underset{\%}{\text { LOI, }}$} & \multirow{2}{*}{$\begin{array}{l}\mathbf{c}, \\
\%\end{array}$} & \multirow{2}{*}{$\underset{\mathrm{kW} / \mathrm{m}^{2}}{\mathbf{q} \mathbf{l}}$} & \multicolumn{2}{|c|}{$\begin{array}{c}\mathbf{D}_{\mathbf{m}}, \\
\mathrm{m}^{2} / \mathrm{kg} \text {, for }\end{array}$} \\
\hline & & & & & pyrolysis & combustion \\
\hline - & 470 & 19.3 & 20.1 & 10.9 & 1350 & 890 \\
\hline $\mathrm{CaO}$ & 480 & 21.2 & 27.0 & 11.7 & 520 & 350 \\
\hline $\mathrm{CaCO}_{3}$ & 495 & 20.5 & 25.1 & 11.4 & 790 & 390 \\
\hline $\mathrm{Ca}(\mathrm{OH})_{2}$ & 480 & 20.1 & 23.8 & 11.2 & 410 & 290 \\
\hline $\mathrm{MgO}$ & 490 & 20.6 & 25.6 & 11.7 & 720 & 400 \\
\hline $\mathrm{Al}_{2} \mathrm{O}_{3}$ & 490 & 20.1 & 23.3 & 10.8 & 800 & 460 \\
\hline $\mathrm{CuO}$ & 480 & 19.8 & 21.8 & 10.6 & 590 & 480 \\
\hline $\mathrm{Fe}_{2} \mathrm{O}_{3}$ & 500 & 21.9 & 29.7 & - & 760 & 500 \\
\hline $\mathrm{Sb}_{2} \mathrm{O}_{3}$ & 510 & 20.6 & 25.4 & 11.2 & 630 & 470 \\
\hline Goethite & 500 & 21.5 & 28.2 & 11.4 & 760 & 500 \\
\hline Grinded quartz sand & 480 & 21.6 & 28.8 & 12.7 & 840 & 540 \\
\hline $\mathrm{Mg}(\mathrm{OH})_{2}$ & 500 & 22.1 & 30.9 & 14.8 & 680 & 330 \\
\hline $\mathrm{Al}(\mathrm{OH})_{3}$ & 515 & 22.3 & 31.6 & 16.2 & 780 & 360 \\
\hline
\end{tabular}

For all the studied composites, a linear dependence between 100/LOI and relative content of mineral fillers $(\mathrm{k})$ is observed. The tangent of the slope of the lines to the abscissa axis $(\operatorname{tg} \alpha)$ is proportional to the specific heat absorption of the filler (Figure 1). The value of tg $\alpha$ can be used to evaluate the efficiency of fillers as fire retardants [16]. The values of $\operatorname{tg} \alpha$ for the plasticized ED-20 polymer are given below:

\begin{tabular}{|c|c|}
\hline Filler & $\operatorname{tg} \boldsymbol{\alpha}$ \\
\hline \hline $\mathrm{Al}_{2} \mathrm{O}_{3}$ & 0.04 \\
\hline $\mathrm{CaCO}_{3}$ & 0.13 \\
\hline $\mathrm{CaO}$ & 0.24 \\
\hline $\mathrm{Serpentine}$ & 1.07 \\
\hline $\mathrm{Al}(\mathrm{OH})_{3}$ & 1.2 \\
\hline $\mathrm{Mg}(\mathrm{OH})_{2}$ & 1.25 \\
\hline Limonite & 1.32 \\
\hline
\end{tabular}




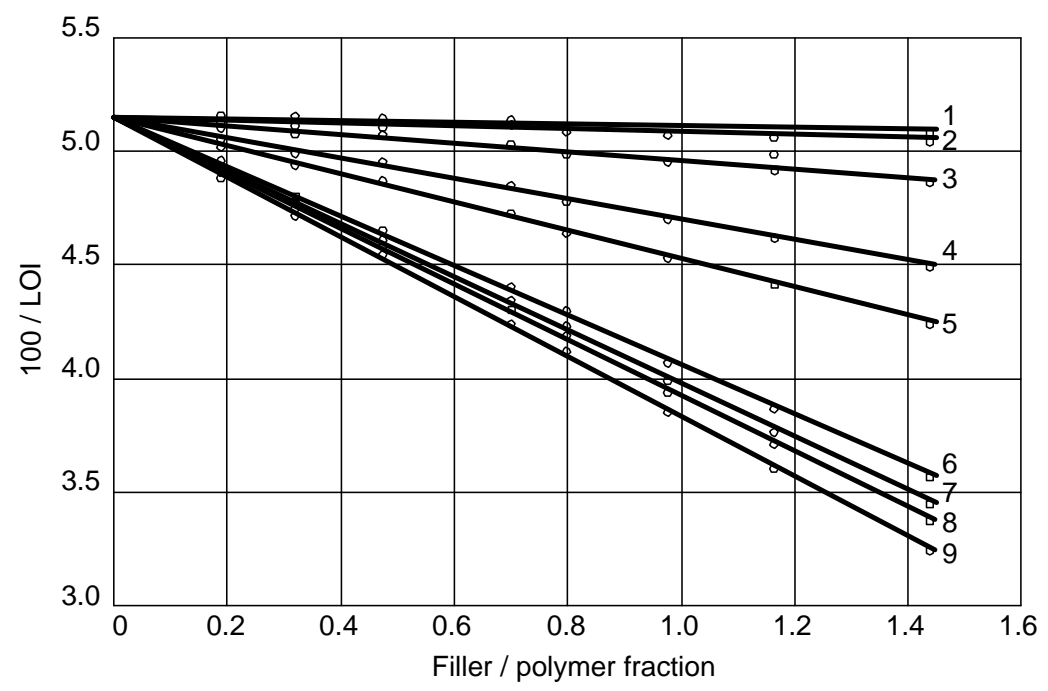

Figure 1. Dependencies between 100/LOI end mineral filler / epoxy polymer fraction for PCM filled with: $\mathbf{1}-\mathrm{Al}_{2} \mathrm{O}_{3} ; \mathbf{2}-\mathrm{CaCO}_{3} ; \mathbf{3}-\mathrm{CaO} ; \mathbf{4}-\mathrm{SiO}_{2} ; \mathbf{5}$ - goethite; $\mathbf{6}$ - serpentine;

$$
7-\mathrm{Al}(\mathrm{OH})_{3} ; 8-\mathrm{Mg}(\mathrm{OH})_{2} ; \mathbf{9} \text { - limonite. }
$$

An effective method of reducing the flammability of epoxy composites is the use of additive brominated fire retardants. As a rule, LOI of such retardants exceeds $90 \%$ (for $\mathrm{N}(2,4,6-$ tribromophenyl) maleimide LOI is $65 \%$ ). Their heat of combustion is $9.4-10.8 \mathrm{~kJ} / \mathrm{kg}$. The influence of the chemical structure of brominated fire retardants (amount is $5.7 \%$ by mass) on the fire hazard of epoxy composites modified with SKN-26-1A synthetic rubber and filled with grinded quartz sand (amount is $41 \%$ by mass) is presented in Table 2 .

Table 2. Fire safety properties of ECM with brominated fire retardants.

\begin{tabular}{|c|c|c|c|c|c|c|}
\hline \multirow[t]{2}{*}{ Type of fire retardant } & \multirow{2}{*}{$\begin{array}{l}\mathbf{T}_{\mathbf{c}}, \\
{ }^{0} \mathrm{C}\end{array}$} & \multirow{2}{*}{ LOI, } & \multirow{2}{*}{$\begin{array}{l}\mathbf{c}_{\mathbf{l}}, \\
\%\end{array}$} & \multirow{2}{*}{$\begin{array}{c}\mathbf{V}_{\mathrm{FS}}, \text { for } \\
{\left[\mathbf{O}_{2}\right]=\mathbf{4 5 \%}} \\
\mathrm{mm} / \mathrm{s}\end{array}$} & \multicolumn{2}{|c|}{$\begin{array}{c}\mathbf{D}_{\mathbf{m}}, \\
\mathrm{m}^{2} / \mathrm{kg}, \text { for }\end{array}$} \\
\hline & & & & & pyrolysis & combustion \\
\hline No fire retardant & 300 & 21.6 & 34.0 & 0.41 & 410 & 570 \\
\hline Pure hexachlorobenzene & 290 & 27.2 & 37.4 & 0.35 & 470 & 580 \\
\hline Hescabromobenzene & 280 & 28.8 & 36.1 & 0.31 & 440 & 1000 \\
\hline Decabromodiphenyl oxide & 270 & 28.2 & 36.8 & 0.25 & 460 & 900 \\
\hline Tetrabrom P-xylene & 270 & 27.9 & 37.9 & 0.33 & 490 & 890 \\
\hline 2,4,6-Tribromaniline & 300 & 28.4 & 36.0 & 0.33 & 480 & 820 \\
\hline $\begin{array}{l}\mathrm{N}(2,4,6 \text {-tribromophenyl)- } \\
\text { maleimide }\end{array}$ & 290 & 28.5 & 36.1 & 0.48 & 430 & 830 \\
\hline Pentabromophenol & 280 & 28.4 & 38.4 & 0.24 & 460 & 360 \\
\hline $\begin{array}{l}\text { 3,5,3', 5'-tetrabromo-4,4'- } \\
\text { diamidiphenylsulfone }\end{array}$ & 295 & 28.1 & 36.1 & 0.35 & 470 & 810 \\
\hline 2,4,6-tribromophenol & 290 & 28.7 & 39.4 & 0.23 & 550 & 820 \\
\hline Tetrabromodiphenylpropane & 290 & 27.2 & 39.6 & 0.45 & - & - \\
\hline Tetrabromphthalic anhydride & 260 & 28.1 & 38.9 & 0.36 & 490 & 900 \\
\hline
\end{tabular}

As it follows from Table 2, aromatic brominated fire retardants reduce the combustibility and flammability of EMC: LOI and $c_{1}$ of composites increase from 21.6 and $34.0 \%$ up to 27.2-28.8 and $36.1-39.6 \%$, respectively; $\mathrm{V}_{\mathrm{FS}}$ decreases from 0.41 down to $0.23-0.31 \mathrm{~mm} / \mathrm{s} ; \mathrm{T}_{\mathrm{i}}$ decreases by $\sim 20{ }^{\circ} \mathrm{C}$, and $\mathrm{T}_{\mathrm{si}}$ is $460-480{ }^{\circ} \mathrm{C}$. $\mathrm{D}_{\mathrm{m}}$ of epoxy composites in the pyrolysis mode slightly increases from 410 to $440-490 \mathrm{~m}^{2} / \mathrm{kg}$, and in the combustion mode it increases from 570 up to 890 $990 \mathrm{~m}^{2} / \mathrm{kg}$. At the same time, the chemical structure of industrial grades of additive aromatic brominated fire retardants has a negligible effect on the combustibility of epoxy composites. It should be noted that purified hexachlorobenzene, while been less efficient than hexabromobenchole, practically does not increase the smoke forming ability of EMC. The mechanism of their action is 
caused both by inhibition of radical chains of processes in the flame, and by the phlegmatization of the flame by products of decomposition of brominated fire retardants.

It should be noted that the LOI of glass-reinforced bromine-containing epoxy resins is well correlated with the flammability index when tested by the ceramic pipe method (Figure 2). As it can be seen from Figure 2, the flame-retardant (low-combustible) composites can be obtained when LOI is more than $31 \%$, and incombustible (moderately combustible) - when LOI is more than $27 \%$.

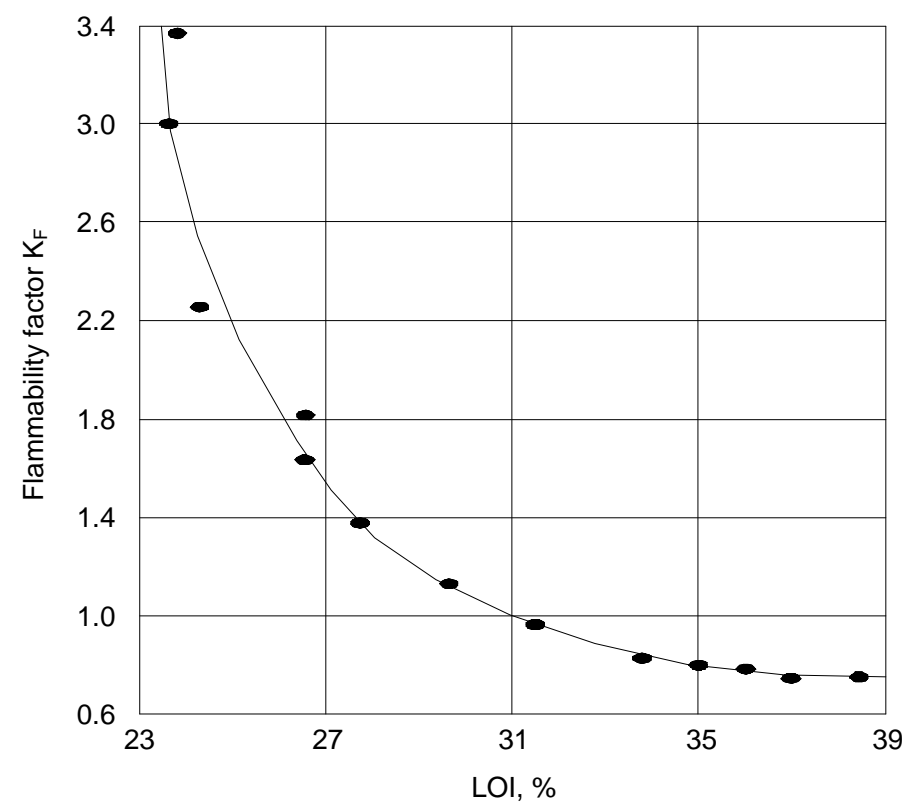

Figure 2. Dependence between LOI and flammability of epoxy composites modified by bromine-organic compounds (ceramic pipe test method).

With the increase of the content of additive brominated fire retardants, the flammability and combustibility of epoxy composites decrease. For example, with an increase of the content of tetrabromodian to $9.8 \%$ the $\mathrm{T}_{\mathrm{i}}$ of EMC decreases from 300 to $280{ }^{0} \mathrm{C}, \mathrm{T}_{\mathrm{si}}$ increases from 460 to $490{ }^{\circ} \mathrm{C}$, and LOI increases from 21.6 to $29.2 \%$. $\mathrm{D}_{\mathrm{m}}$ in pyrolysis mode is practically independent of the content of fire retardants and its value is $420-440 \mathrm{~m}^{2} / \mathrm{kg}$. In the combustion mode $\mathrm{D}_{\mathrm{m}}$ increases from 570 to $990 \mathrm{~m}^{2} / \mathrm{kg}$. The dependence between LOI of ECM and amount of bromine in the composite is shown in Figure 3.

Influence of Redant bromine-organic fire retardants on the heat resistance and fire hazard of EMC is shown in Table 3 (amount of fire retardants is $8.6 \%$ by mass, amount of marshalite is $47.2 \%$ by mass). EMC modified with Redant $1-\mathrm{C}$ have a higher thermal conductivity (the specific heat of combustion of the composition containing $20 \mathrm{wt}$. parts of Redant 1 is $31570 \mathrm{~kJ} / \mathrm{kg}$, while for materials modified with Redant 2 and Redant 1-2 these values are 29030 and $29900 \mathrm{~kJ} / \mathrm{kg}$, respectively) and also characterized by reduced heat resistance. The mass burnup rate of composites modified with 20 wt. parts of Redant 1 and Redant $2-1$ are 32,17 and $30.59 \mathrm{~g} /\left(\mathrm{m}^{2} \cdot \mathrm{s}\right)$, respectively, with a heat flux density of $10.58 \mathrm{~kW} / \mathrm{m}^{2}$.

Considering that additive brominated fire retardants are crystalline or amphoric powders, is was suggested to use them in form of solution in N,N-dimethyl-2,4,6-tribromoaniline. It was revealed that as the concentration of Redant 1 in N,N-dimethyl-2,4,6-tribromoaniline increases up to 50\%, the LOI of composites increase from $25.8 \%$ to $30.1 \%$, mass burnup rate at a warm flux density of $10.58 \mathrm{~kW} / \mathrm{m}^{2}$ is reduced from 29.1 to $23.4 \mathrm{~g} /\left(\mathrm{m}^{2} \mathrm{~s}\right)$, and the heat of combustion decreases linearly from 34400 to $30150 \mathrm{~kJ} / \mathrm{kg}$ (Figure 4). The maximum values of Dm were observed for composites with 20-30\% solution of Redant 1 in N,N-dimethyl-2,4,6-tribromoaniline (Figure 5). The use of Redant fire retardants in form of solution in $\mathrm{N}, \mathrm{N}$-dimethyl-2,4,6-tribromanyline makes it possible to produce low-combustible EMC and eliminate flame propagation over the surface. 


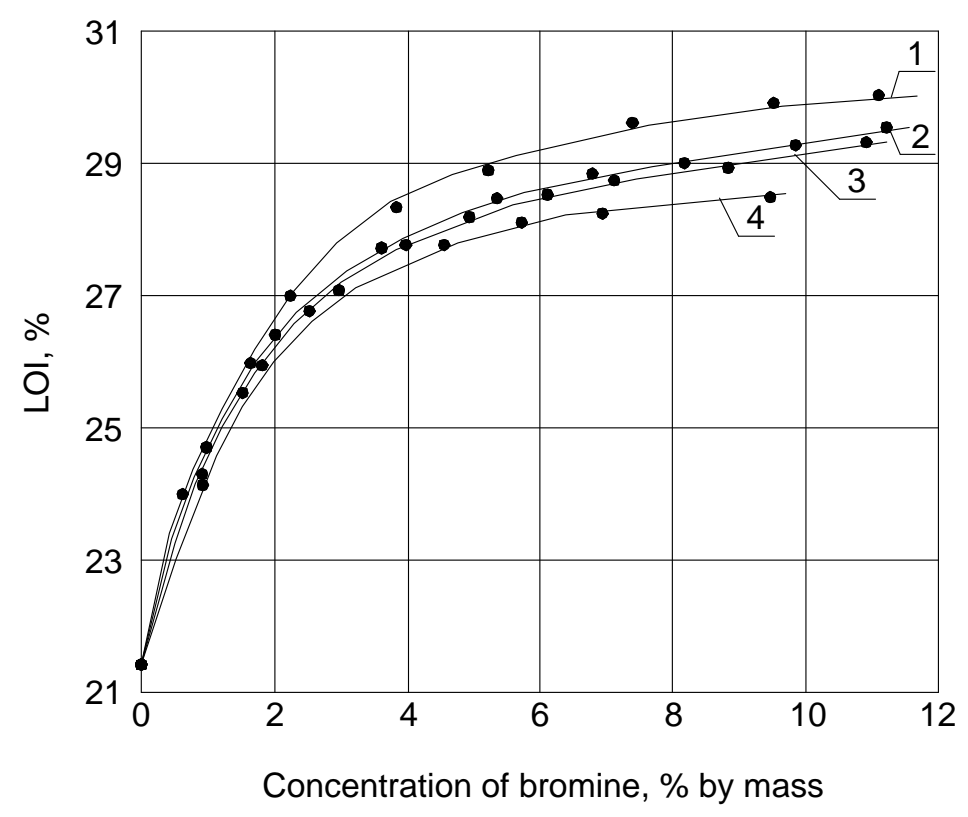

Figure 3. Dependence between concentration of bromine in the material and LOI for epoxy composites with additive bromine-organic fire retardants: $\mathbf{1}$ - hexabromobenzene; $\mathbf{2}$ - decabromodiphenyl oxide; 3 - 2,4,6-tribromanylene; 4 - N(2,4,6-tribromophenyl)maleimide.

Table 3. Thermal stability, combustibility and fume evolution of epoxy matrix composites.

\begin{tabular}{|c|c|c|c|c|}
\hline \multirow{2}{*}{ Properties } & \multicolumn{4}{|c|}{ Type of fire retardant } \\
\hline & Redant 1-2 & Redant 2-1 & Redant 2 & Redant 1 \\
\hline LOI, $\%$ & 32.3 & 33.2 & 30.5 & 33.7 \\
\hline $\begin{array}{l}\text { Temperature, }{ }^{0} \mathrm{C} \\
\text { beginning of decomposition } \\
\text { maximal rate of decomposition for: }\end{array}$ & 284 & 252 & 253 & 264 \\
\hline - $\quad$ stage 1 & 317 & 322 & 322 & 333 \\
\hline - $\quad$ stage 2 & 447 & 445 & 447 & 440 \\
\hline $\begin{array}{l}\text { Flame spread rate, } \mathrm{mm} / \mathrm{s} \text {, for } \\
\text { oxygen concentration: } \\
\text { - } 40 \% \\
\text { - } 50 \%\end{array}$ & $\begin{array}{c}- \\
0.48\end{array}$ & $\begin{array}{c}0.27 \\
0.5\end{array}$ & $\begin{array}{c}- \\
0.56\end{array}$ & $\begin{array}{l}0.27 \\
0.46\end{array}$ \\
\hline Heat of combustion, $\mathrm{kJ} / \mathrm{kg}$ & 29900 & - & 29030 & 31570 \\
\hline $\begin{array}{l}\text { Fume evolution, } \mathrm{m}^{2} / \mathrm{kg} \text {, for } \\
\text { - } \quad \text { pyrolysis } \\
\text { - } \quad \text { combustion }\end{array}$ & $\begin{array}{l}770 \\
650\end{array}$ & $\begin{array}{l}870 \\
730\end{array}$ & $\begin{array}{l}760 \\
690\end{array}$ & $\begin{array}{l}850 \\
630\end{array}$ \\
\hline
\end{tabular}

Thus, the use of industrial grades of additive brominated fire retardants allows the production of EMC with LOI of $31-33 \%$ for bromine concentration of $6-8 \%$ by mass. The optimal amount of such fire retardants is $8-10 \%$ by mass. For such concentation, the strength of EMC is only slightly reduced. The mechanism of action of bromine-containing fire retardants was considered in detail in [23-25].

The effect of the content of reactive bromine-containing epoxy compounds on the combustibility of cured binders is shown in Figure 6. As it follows from Figure 6, bromine-containing epoxy oligomer UP-631 is more effective than aniline-modified diglycidyl ether of tetrabromodiamine and brominated ED-22 epoxy oligomer. This is due to different concentration of bromine in these epoxy compounds. This conclusion is confirmed by the experimentally observed linear dependence between the LOI epoxy polymers and bromine concentration (Figure 7). 


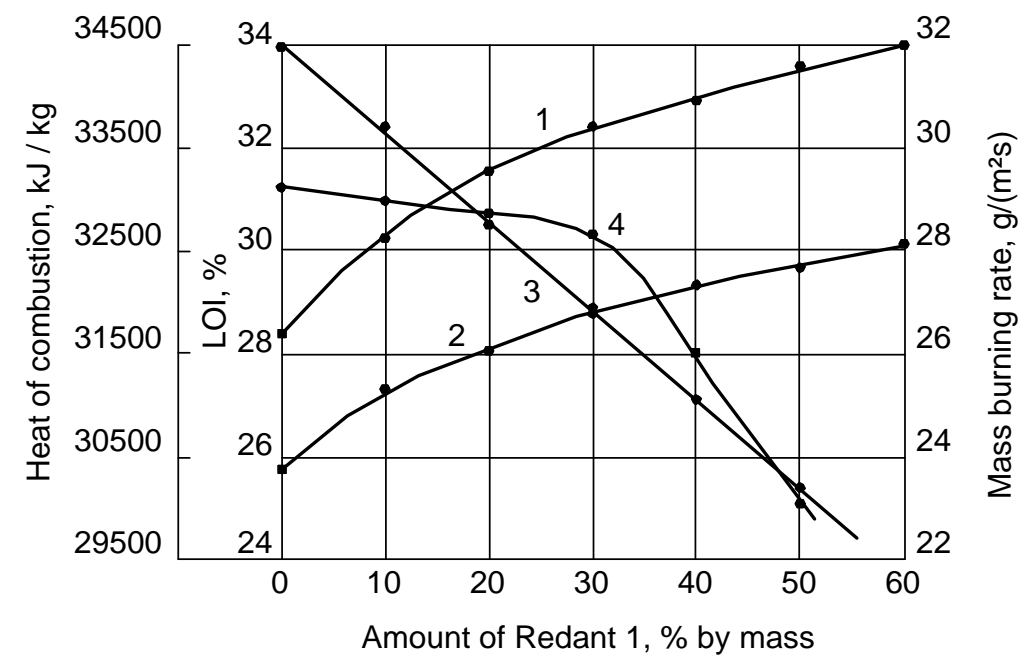

Figure 4. Dependencies between combustibility of epoxy matrix composites and amount of Redant 1 in N, $\mathrm{N}$-dimethyl-2,4,6-tribromoaniline: 1, 2 - LOI; $\mathbf{3}$ - heat of combustion; $\mathbf{4}$ - mass burning rate; $\mathbf{1}$ - amount of fire retardant in the composition is $8.6 \%$ by mass; $\mathbf{2 , 3 , 4}-4.5 \%$ by mass.

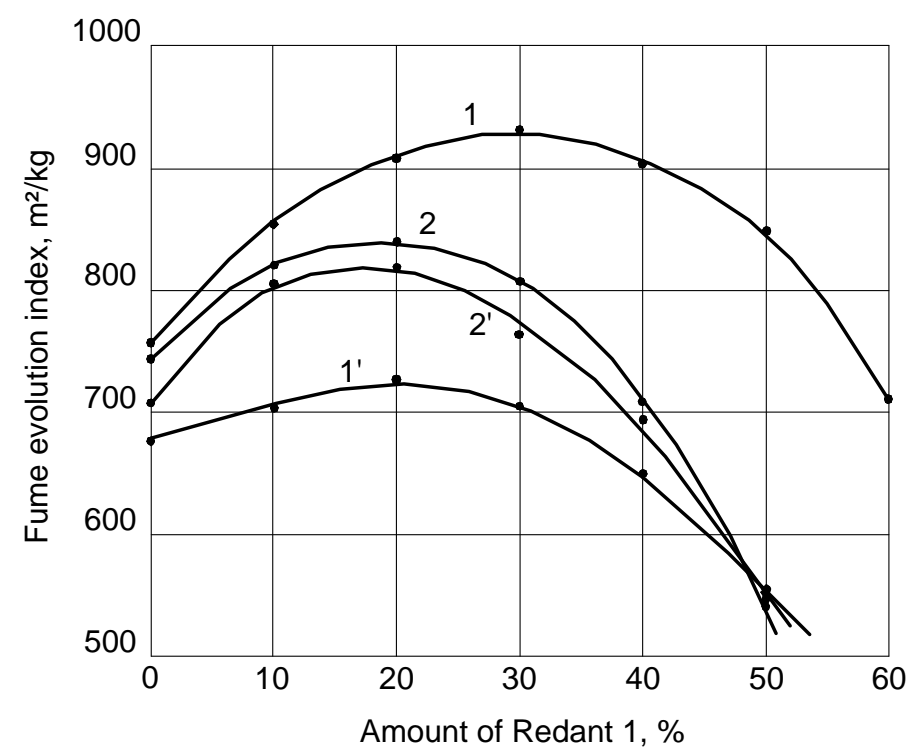

Figure 5. Dependencies between fume evolution of epoxy matrix composites and amount of Redant 1 in $\mathrm{N}$, N-dimethyl-2,4,6-tribromoaniline: 1, 2 - pyrolysis mode; 1', 2' - flaming combustion;

$\mathbf{1 , 1 ^ { \prime }}$ - amount of fire retardant is $4.1 \%$ by mass; $\mathbf{2}, \mathbf{2}^{\prime}-7.9 \%$ by mass.

It should be noted that reactive bromine-containing compounds are significantly less efficient than additive fire retardants. For example, to obtain composites with LOI equal to $27 \%$, the concentration of bromine in the composition with pentabromophenol has to be $8.3 \%$, while concentation of bromine-containing UP-631 oligomer has to be $20 \%$. This is due to higher concentration of bromine in additive brominated fore retardants (58-86\%) compared to brominecontaining epoxy compounds (bromine concentration is 25.0-48.8 


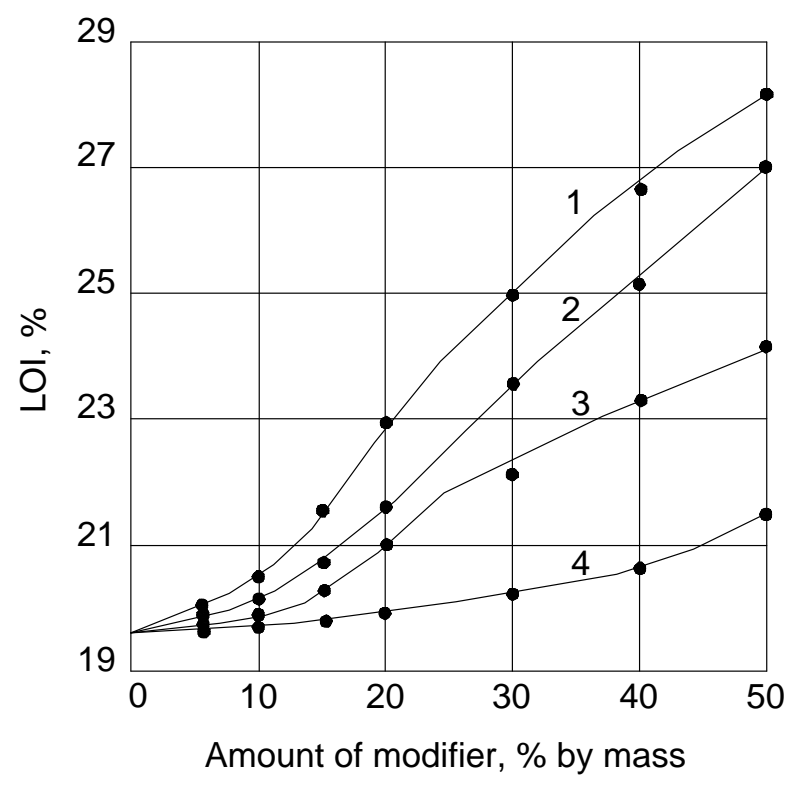

Figure 6. Dependence between flammability of cured ED-20 epoxy resin and concentration of halogencontaining modifiers: 1 - bromine-containing UP-631 oligomer; 2 - modified diglycidyl ether of tetrabromodian at 1:1 molar ratio between UP-631 and aniline; $\mathbf{3}$ - brominated ED-22 oligomer with a bromine concentration of $25 \%$ by mass; 4 - chlorine-containing Oxylin- 6 oligomer.

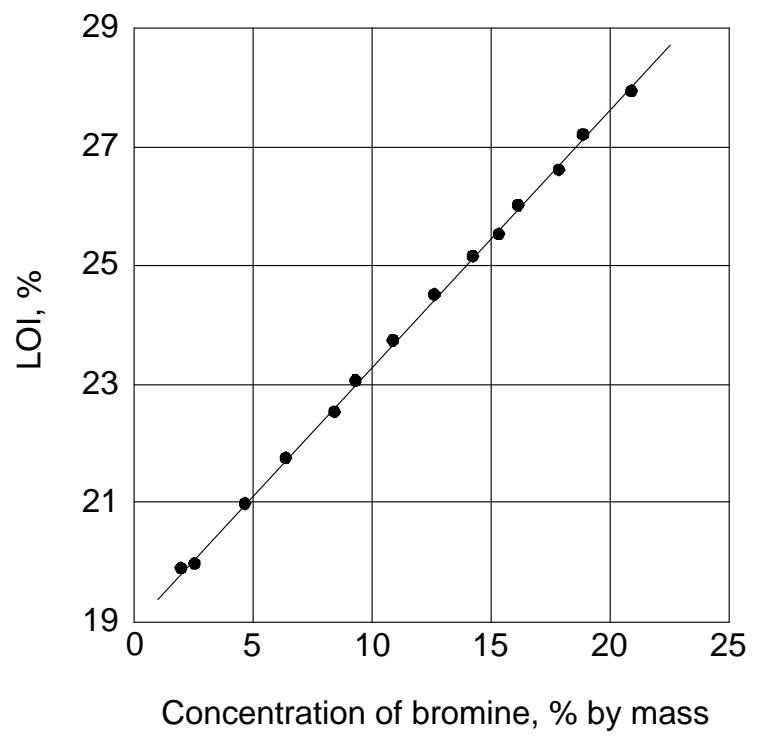

Figure 7. Dependence between concentration of bromine and LOI of cured epoxy binders.

The promising direction of reducing the combustibility of EMC is the use of microencapsulated fire retardants. Microcapsules containing fire retardants explosively break down when exposed to elevated temperatures or flames, throwing the vaporized flame-extinguishing agent into the flame zone. As an example, Figure 8 illustrates the effect of the content of microencapsulated fire retardants on the combustibility of EMC. In this case, the microencapsulated DBDFO is inferior to the ordinary DBDFO. The efficiency of microencapsulated fire retardants depends mainly on the diameter of the microspheres, chemical nature of the fire retardant used and, to a lesser extent, on the chemical nature of the microcapsule shell. The effects of microencapsulated DBDFO (5.85\% by mass) on the combustibility of epoxy composites filled with marshallite $(41.8 \%$ by mass) are summarized in Table 4. 


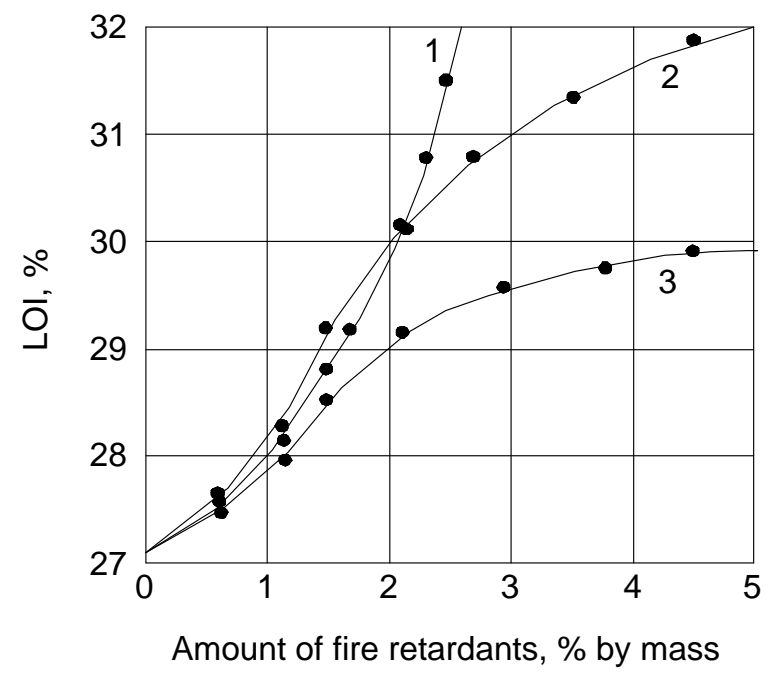

Figure 8. Dependence between content of microencapsulated fire retardants and LOI of epoxy materials: 1 - ammonium polyphosphate; 2 - Chladon-114V2; 3 - carbon tetrachloride.

Table 4. LOI of epoxy compositions with decabromodiphenyl oxide.

\begin{tabular}{|l|c|}
\hline \multicolumn{1}{|c|}{ Type of decabromodiphenyl oxide } & LOI, \% \\
\hline DBDPO with a particle diameter of $240 \mu \mathrm{m}$ & 36.9 \\
\hline DBDPO with a shell of epoxy resin with a particle diameter of $150-400 \mu \mathrm{m}$ & 33.1 \\
\hline DBDPO with a shell of epoxy resin with a particle diameter of at least $150 \mu \mathrm{m}$ & 32.1 \\
\hline $\begin{array}{l}\text { DBDPO with a shell of a copolymer of styrene and N(2.4.6-tribromophenyl)-maleimide with a particle } \\
\text { diameter of at least } 150 \mu \mathrm{m}\end{array}$ & 32.8 \\
\hline $\begin{array}{l}\text { DBDPO with a shell of a copolymer of styrene and N(2.4.6-tribromophenyl)-maleimide with a particle } \\
\text { diameter of not more than } 150 \mu \mathrm{m}\end{array}$ & 32.1 \\
\hline DBDPO with a shell of an aromatic polyamide with a particle diameter of $150-400 \mu \mathrm{m}$ & 32.1 \\
\hline DBDPO with a shell of an aromatic polyamide with a particle diameter of at least $150 \mu \mathrm{m}$ & 28.6 \\
\hline Chladon-II4B2 with a shell of polyvinyl alcohol with a particle diameter of $125-250 \mu \mathrm{m}$ & \\
\hline
\end{tabular}

The effective smoke suppressor of polymeric materials is ferrocene (Figure 9). It has been established that the cyclopentadienyl sandwich-like derivatives of iron do not affect the ignition temperature $\left(220-230^{\circ} \mathrm{C}\right)$ and decomposition of epoxy compositions in the low-temperature region (Table 5), but significantly affect pyrolysis at temperatures above $300{ }^{\circ} \mathrm{C}$. In later case, the higher the efficiency of the ferrocene derivatives, the higher the decomposition rate of the epoxy composites in the second stage. The LOI of EMC with ferrocene derivatives can also be increased (Figure 10).

The high efficiency of acetyl- and $\alpha$-hydroxyethylferrocene in comparison with ordinary ferrocene is due to the ease of formation of ultradispersed catalytically active iron oxides $\left(\mathrm{Fe}_{2} \mathrm{O}_{3}\right.$, $\mathrm{Fe}_{3} \mathrm{O}_{4}$ ) during pyrolysis of derivatives. This affects the mechanism of pyrolysis of carbonizing polymers, increases the probability of formation of carbonized layer on the surface of the polymer, supresses formation of benzene and smoke. Optimal concentration of ferrocene derivatives in EMC is $0.3-0.5 \%$ by mass. 


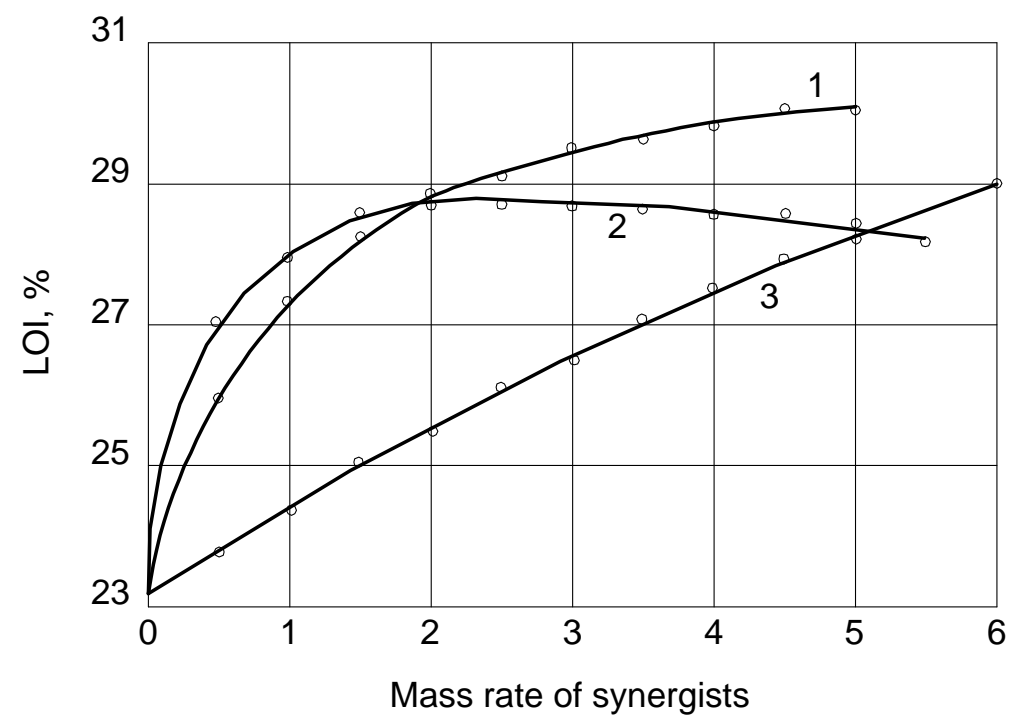

Figure 9. Dependencies between LOI of epoxy matrix composites and amount of synergists: $\mathbf{1}$ - ferrocene; $\mathbf{2}$ - boron; $\mathbf{3}-\mathrm{Sb}_{2} \mathrm{O}_{3}$.

Table 5. Thermal stability and combustibility of filled epoxy matrix composites (amount of filler is $35 \%$ by mass) with $0.29 \%$ by mass of ferrocene derivatives.

\begin{tabular}{|c|c|c|c|c|c|c|c|}
\hline Properties & 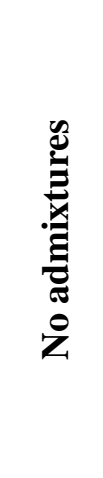 & & 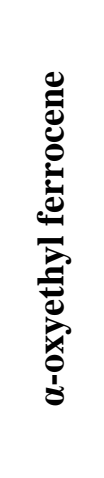 & & 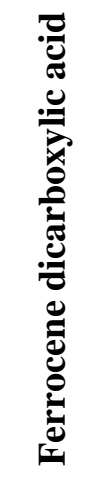 & 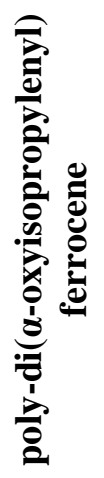 & $\mathrm{Sb}_{2} \mathrm{O}_{3}$ \\
\hline $\begin{array}{l}\text { Temperature, }{ }^{0} \mathrm{C}: \\
\text { - } \quad \text { ignition } \\
\text { - } \text { start of decomposition } \\
\text { - } \text { maximal rate of decomposition } \\
* \text { on the first stage } \\
* \text { on the second stage } \\
\text { self ignition }\end{array}$ & $\begin{array}{l}220 \\
284 \\
\\
304 \\
485 \\
515\end{array}$ & $\begin{array}{l}240 \\
276 \\
\\
301 \\
500 \\
490\end{array}$ & $\begin{array}{l}230 \\
285 \\
\\
305 \\
468 \\
470\end{array}$ & $\begin{array}{l}220 \\
273 \\
\\
300 \\
459 \\
480\end{array}$ & $\begin{array}{l}220 \\
284 \\
\\
305 \\
483 \\
480\end{array}$ & $\begin{array}{l}220 \\
282 \\
\\
306 \\
481 \\
480\end{array}$ & $\begin{array}{c}- \\
284 \\
306 \\
496 \\
-\end{array}$ \\
\hline $\begin{array}{l}\text { Maximal rate } \\
\text { decomposition, \%/min, } \\
\text { - on the first stage } \\
\text { - on the second stage } \\
\text { Specific heat of decomposition, } \\
\mathrm{kJ} / \mathrm{kg} \\
\mathrm{LOI} \%\end{array}$ & $\begin{array}{c}19.9 \\
18.9 \\
4070 \\
23.3\end{array}$ & $\begin{array}{c}19.9 \\
24.2 \\
4300 \\
27.6\end{array}$ & $\begin{array}{c}20.0 \\
24.5 \\
3960 \\
28.3\end{array}$ & $\begin{array}{c}21.2 \\
20.8 \\
4300 \\
25.6\end{array}$ & $\begin{array}{c}18.4 \\
18.8 \\
4300 \\
26.1\end{array}$ & $\begin{array}{c}21.4 \\
16.0 \\
3300 \\
25.8\end{array}$ & $\begin{array}{c}22.2 \\
22.9 \\
4360 \\
27.9\end{array}$ \\
\hline
\end{tabular}




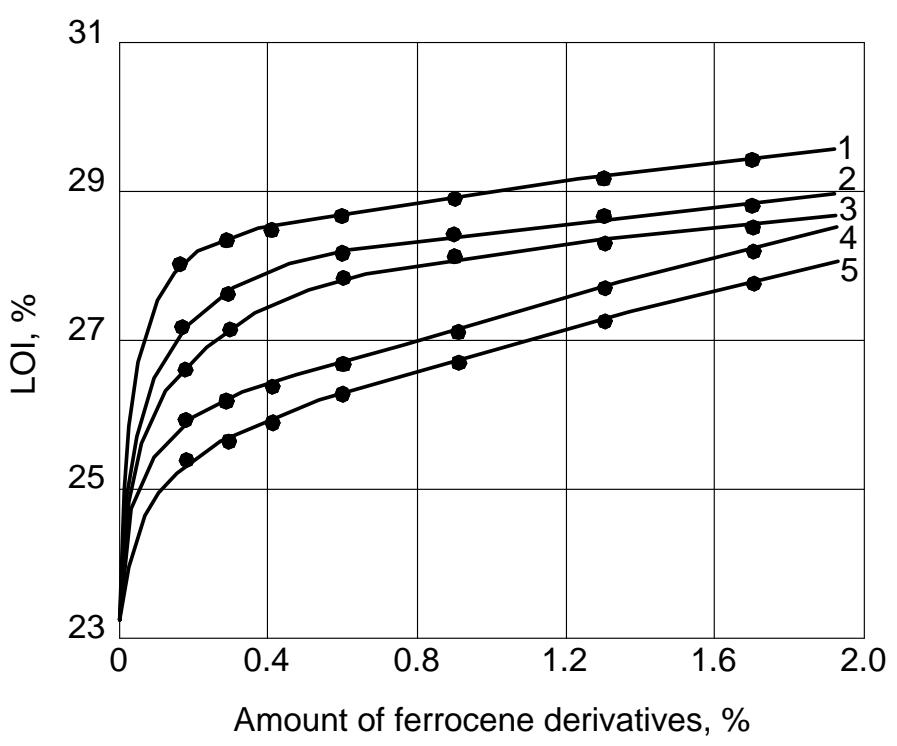

Figure 10. Dependence between LOI of epoxy matrix mortars and amount of ferrocene derivatives: $\mathbf{1}$ - $\alpha$-oxyethylferrocene; $\mathbf{2}$ - ferrocene; $\mathbf{3}$ - diacetylferrocene; $\mathbf{4}$ - ferrocenedicarboxylic acid; 5 -acetylferrocene.

\section{Conclusion}

In the present work, we summarized and discussed the results of several laboratory tests. The tests were carried out to answer the question concerning the suitability and effectiveness of different measures that allow to reduce fire hazards of EMC. Considerable amount of experimental data concerning properties of EMC was obtained. Influence of the type and content of different fillers and fire retardants to the heat resistance, ignitability, flammability and smoke-forming ability of EMC was examined. The compositions of EMC that are characterized by elevated performance properties, including low combustibility, are determined. The developed composites successfully can be used in the construction industry.

\section{References}

[1] Chrusciel J.J., Lesniak E. Modification of epoxy resins with functional silanes, polysiloxanes, silsesquioxanes, silica and silicates. Progress in Polymer Science, 2015, vol. 41, pp. 67-121.

[2] Khozin V.G. . Strengthening the Epoxy Polymers. Kazan: PIC Publishing House, 2004. 446 p. (in Russian)

[3] Zaytsev Yu.S. Epoxy oligomers and compositions. Kiev, Naukova dumka, 1990. 200 p. (in Russian)

[4] Kochnova Z.L., Zhavoronok E.S., Chalykh A.E. Epoxy resins and hardeners: industrial products. Moscow, "Peynt-Media", 2006. 200 p. (in Russian)

[5] Chernin I.Z., Smekhov F.M., Zherdev Yu.Z. Epoxy polymers and compositions. Moscow, Khimiya, 1982. 232 p. (in Russian)

[6] Bazhenov S.L., Berlin A.A., Kul'kov A.A., Oshmyan V.G. Polymer matrix composites. Strength and technology. Dolgoprudnyy, Intelligence, 2010. 347 p. (in Russian)

[7] Bazhenov Yu.M. Sustainable materials and technologies for repair and reconstruction of buildings and constructions. Moscow, "Komtekh-Print", 2006. 235 p. (in Russian)

[8] Stepanova V.F., Stepanov A.Yu., Zhirkov E.P. Polymer matrix composite reinforcement]. Moscow, "Bumazhnik", 2013. 200 p. (in Russian)

[9] Shilin A.A., Pshenichnyy V.A., Kartuzov D.V. External reinforcement of ferroconcrete by composite materials. Moscow, "Stroyizdat", 2007. 184 p. (in Russian) 
[10] Selyaev V.P., Ivashchenko Yu.G., Nizina T.A. Polymer matrix concrete. Saransk, Publishing house of the Mordovian State University, 2016. 284s.

[11] Gladkikh V.A., Korolev E.V., Smirnov V.A., Sukhachev I.S. Modeling the Rutting Kinetics of the Sulfur-extended Asphalt. Procedia Engineering, 2016, vol. 165, pp. 1417-1423.

[12]Bruyako M.G., Glukhoedov V.A., Kravtsova D.V., Smirnov V.A., Ushkov, V.A. Plasma processing in industry of building materials. Advanced Materials Research, 2014, vol. 1040, pp. 730734.

[13]Polymers of low flammability. Ed. by Provednikova A.N. Moscow, Khimiya, 1989. 224 p. (in Russian)

[14] Mikhaylin Yu.A. Thermal stability and fire resistance of polymers. Saint Petersburg, Scientific foundations and technologies, 2011. 416 p. (in Russian)

[15] Karbhari V., Chin J., Hunston D., Benmokrane B., Juska T., Morgan R. Lesko J., Sorathia U., Reynaud D. Durability Gap Analysis for Fiber-Reinforced Polymer Composites in Civil Infrastructure. J. Compos. Constr, 2003, vol. 7, no. 3, pp. 238-247.

[16]Bakis C., Bank L., Brown V., Cosenza E., Davalos J., Lesko J., Machida A., Rizkalla S., Triantafillou T. Fiber-Reinforced Polymer Composites for Construction - State-of-the-Art Review. J. Compos. Constr, 2002, vol. 6, no. 2. pp. 73-87.

[17] Mouritz A.P. Gibson A.G. Fire Properties of Polymer Composite Materials. Dordrecht: Springer, 2006. 400 p.

[18] Askadsky A.A., Ushkov V.A., Smirnov V.A. Polymer Composites with Ferrocene Derivatives for Fire-safe Construction. Proc. of Intl. Conf. on Advanced Materials, Structures and Mechanical Engineering ICAMSME 2015, 2016, pp. 365-370.

[19]Ushkov V.A., Kopytin A.V., Smirnov V.A., Alimov L.A. Plasticized Polymer Matrix Composites for Fire-safe Construction. Procedia Engineering, 2016, vol. 165, pp. 1823-1828.

[20] Askadsky A.A., Ushkov V.A., Smirnov V.A., Voronin V.V. Flammability of the disperse-filled polymer composites. Solid State Phenomena, 2016, vol. 871, pp. 40-46.

[21] Polymer Green Flame Retardants. Ed. by Papaspyrides C.D., Kiliaris P. Amsterdam: Elsevier, 2014. 919 p.

[22] Dufton P. Flame Retardants for Plastics. Shawbury: Smithers Rapra Press, 2003. 147 p.

[23] Kandare E., Kandola B.K., Myler P. Evaluating the Influence of Varied Fire-retardant Surface Coatings on Post-Heat Flexural Properties of Glass/Epoxy Composites. Fire Safety Journal, 2013, vol. 58, pp. 112-120.

[24] Manley T.R., Sidebotham S. The Flammability at Elevated Temperatures of Polyester Resins Containing Antimony Oxide and Halogens. Fire Safety Journal, 1980, vol. 3, pp. 25-29.

[25] Georlette P. Applications of Halogen Flame Retardants. In: Fire Retardant Materials. Ed. by A.R. Horrocks, D. Price. Sawston: Woodhead, 2001. pp. 264-292.

[26] Schartel B. Phosphorus-based Flame Retardancy Mechanisms - Old Hat or a Starting Point for Future Development? Materials, 2010, vol. 3, pp. 4710-4745.

[27] Mauerer O. New Reactive, Halogen-free Flame Retardant System for Epoxy Resins. Polymer Degradation and Stability, 2005, vol. 88, pp. 70-73.

[28]Luo C., Zuo J., Wang F., Yuan Y., Lin F., Huang H., Zhao J. High Refractive Index and Flame Retardancy of Epoxy Thermoset Cured by Tris(2-mercaptoethyl)phosphate. Polymer Degradation and Stability, 2016, vol. 129, pp. 7-11.

[29]Chen X., Jiao C., Li S., Hu Y.. Preparation and Properties of a Single Molecule Intumescent Flame Retardant. Fire Safety Journal, 2013, vol. 58, pp. 208-212.

[30]Lim K., Bee S., Sin L.T., Tee T., Ratnam C.T., Hui D., Rahmat A.R. A Review of Application of Ammonium Polyphosphate as Intumescent Flame Retardant in Thermoplastic Composites. Composites Part B: Engineering, 2016, vol. 84, pp. 155-174. 
[31]Naik A.D., Fontaine G., Samyn F., Delva X., Louisy J., Bellayer S., Bourgeois Y., Bourbigot S. Outlining the Mechanism of Flame Retardancy in Polyamide 66 Blended with Melamine-poly(zinc phosphate). Fire Safety Journal, 2014, vol. 70, pp. 46-60.

[32] Kishore K., Kannan P., Iyanar K. Synthesis, Characterization and Fire Retardancy of Ferrocene Containing Poly-phosphate Esters. Journal of Polymer Science Part A: Polymer Chemistry, 1991, vol. 29, pp. 1039-1044.

[33]Zhang J., Megaridis C.M. Iron/soot Interaction in a Laminar Ethylene Nonpremixed Flame. Proc. of Twenty-fifth Symposium on Combustion, 1994, vol. 25, pp. 593-600.

[34]Carty P., Grant J., Metcalfe E. Flame-retardancy and Smoke-suppression studies of ferrocene derivatives in PVC. Applied Organometallic Chemistry, 1996, vol. 10, pp. 101-111.

[35] Ushkov V.A., Lalayan V.M., Nevzorov D.I., Lomakin S.M. Flammability and fume evolution of polymer matrix composites with phosphate and phthalate modifiers. Pozharovzryvobezopasnost', 2013, vol. 22, no. 10, pp. 25-31. (in Russian)

[36] Ushkov V.A., Lalayan V.M., Lomakin S.M., Nevzorov D.I. Flammability and fume evolution of polymer matrix composites with non-decomposable fillers]. Pozharovzryvobezopasnost' , 2013, vol. 22, no. 6, pp. 33-37 (in Russian).

[37]Ushkov V.A., Lalayan V.M., Lomakin S.M., Nevzorov D.I. ,Combustibility and fume evolution of polymer matrix composites with decomposable mineral fillers. Pozharovzryvobezopasnost' 2013, vol. 22, no. 8, pp. 15-22. (in Russian)

[38] Ushkov V.A., Abramov V.V., Grigor'eva L.S., Kir'yanova L.V. Thermal stability and fire safety of epoxy mortars. Stroitel'nye materialy, 2011, no. 12, pp. 68-71. (in Russian)

[39] Ushkov V.A., Grigor'eva L.S., Abramov V.V. Combustibility of epoxy polymers. Vestnik MGSU , 2011, vol. 2, no. 1, pp. 352-356. (in Russian)

[40] Ushkov V.A., Nevzorov D.N., Kopytin A.V., Lalayan V.M. Flammability and fume evolution of polymer matrix composites with ferrocene derivatives]. Pozharovzryvobezopasnost', 2014, vol. 23, no. 7, pp. 27-35. (in Russian)

[41]Ushkov V.A., Abramov V.V., Lalayan V.M., Kir'yanova L.V. Epoxy mortars of low combustibility for repair and restoration of constructions. Pozharovzryvobezopasnost', 2012, vol. 21, no. 10 , pp. 36-40. (in Russian)

[42]1Panina N.N., Chursova L.V., Babin A.N., Grebeneva T.A., Gurevich Ya.M. The most used ways of modifications of epoxy polymers that are common in Russia. Vse materialy. Entsiklopedicheskiy spravochnik , 2014, no. 9, pp. 10-17. (in Russian)

[43]Bryk M.T. Destruction of the filled polymers: monograph. Moscow, Khimiya, 1989. 192 p. (in Russian)

[44] Khalturinskiy N.A. O Vse materialy. Entsiklopedicheskiy spravochnik, 2009, no. 11, pp. 22-30. (in Russian)

[45] Khalturinskiy N.A. Processes that causes the destruction of halide retardants]. Vse materialy. Entsiklopedicheskiy spravochnik, 2009, no. 12, pp. 30-37. (in Russian)

[46] Khalturinskiy N.A., Rudakova T.A. Physics of combustion of polymers and processes that causes the effect of retardants. Khimicheskaya fizika], 2008, vol. 27, no. 6, pp. 73-84. (in Russian)

[47]Phosphonamidates-synthesis and flame retardant applications, United States Patent 9,650,497 